\title{
References:
}

1. Bader FG, Schröder M, Kujath P, et al. Diffuse postoperative peritonitis - value of diagnostic parameters and impact of early indication for relaparotomy. Eur J Med Res. 2009 Nov 3;14(11):491-6. doi: 10.1186/2047-783x14-11-491.

2. Sartelli M, Viale P, Catena F, et al. 2013 WSES guidelines for management of intra-abdominal infections 2013 WSES guidelines for management of intra-abdominal infections. World J Emerg Surg. 2013;8(1):3. doi:10.1186/1749-7922-8-3

3. Eckmann C, Bassetti M. Prognostic factors for mortality in (fecal) peritonitis: back to the roots. Intensive Care Med. 2014;40(2):269-271. doi:10.1007/s00134-013-3155-x

DOI https://doi.org/10.30525/978-9934-26-038-4-25

\section{ПРОГНОЗ ЗВИЧНОГО НЕВИНОШУВАННЯ ВАГІТНОСТІ}

\author{
Лоскутова Т. О. \\ доктор медичних наук, \\ професор кафедри акушерства та гінекологіі \\ Д3 «Дніпропетровська медична академія \\ Міністерства охорони здоров'я Украӥни» \\ м. Дніпро, Украӥна
}

Давиденко Н. В.

лікар акушер-гінеколог

Комунальне некомериійне підприємство «Міська поліклініка № 4»

Дніпропетровської міської ради

м. Дніпро, Украӥна

Чулков О. С.

лікар-інтерн кафедри акушерства, гінекології та перинатології

факультету післядипломної освіти

Д3 «Дніпропетровська медична академія

Міністерства охорони здоров'я України»

м. Дніпро, Украӥна

Актуальність. Частота невиношування вагітності стабільно залишається високою та досягає 30 \% від кількості бажаних вагітностей. Статистично кожен другий випадок мимовільного переривання вагітності трапляється у 1 триместрі, а $25 \% 3$ них припадає на звичне 
невиношування вагітності, що безумовно потребує предикції задля виявлення пацієнток високого ризику, їх лікування та покращення демографічної ситуаціії [4].

Мета дослідження. Створити прогностичну модель звичного невиношування вагітності на підставі визначення наявності мутації генів PAI-1 (675 5G/4G), та в гені фібриногену $\beta 455 \mathrm{G} \rightarrow \mathrm{A}$ та оцінити їі ефективність.

Матеріали і методи. Для реалізації поставленої мети було обстежено 143 жінки в першому триместрі вагітності. Основну групу (О) склали 109 жінок зі ЗНВ. Контрольну групу (К) склали 34 умовно здорових вагітних з необтяжливим анамнезом та перебігом вагітності без наявності факторів ризику розвитку невиношування. Для постановки діагнозу звичного невиношування вагітності послугувались наказом МO3 України № 624 від 03.112008 року, а саме: дві або більше вагітностей поспіль, що закінчились викиднем. Проводили визначення поліморфізмів в генах 675 5G/4G інгібітору активатора плазміногена 1 типа (PAI-1) та в гені фібриногену $\beta 455 \mathrm{G} \rightarrow \mathrm{A}$ за допомогою алельспецифічної полімеразної ланцюгової реакції з наступною детекцією методом електрофорезу в $3 \%$ агарозному гелі. Статистичну обробку результатів дослідження проводили 3 використанням ліцензійних комп'ютерних програм Microsoft Excel 2010 i Graph Pad Prism 5 (номер ліцензії 35B73650-6899-11DA-6784-00232A9018BE). [5].

Результати та їх обговорення. Запропоновано розгляд таких чинників: поліморфізми в геномі людини: 675 5G/4G в гені інгібітора активатора плазміногену - 1 (PAI-1) та поліморфізм в гені фібриногену $\beta$ $455 \mathrm{G} \rightarrow \mathrm{A}$. Вибір грунтується на нижченаведених фактах (таблиця 1).

Таблиця 1

Розподіл поліморфізма генів 5G/4G PAI-1 та 455 G $\rightarrow$ A фібриногену $\beta$ у обстежених вагітних, n(\%)

\begin{tabular}{|l|l|l|l|l|l|l|l|}
\hline $\begin{array}{l}\text { Поліморфізм } \\
\text { генів }\end{array}$ & $\begin{array}{l}\text { К група } \\
\mathrm{n}=34\end{array}$ & $\begin{array}{l}\text { О група } \\
\mathrm{n}=109\end{array}$ & Разом & $\mathrm{p}$ & ВШ & $95 \%$ ДI \\
\hline 5G/4G PAI-1 & 19 & 18 & 37 & & & & \\
\hline \multirow{2}{*}{ 5G/5G PAI-1 } & $55,9 \%$ & $16,5 \%$ & $25,9 \%$ & $<0,0001$ & 0,16 & $0,07-0,36$ \\
\cline { 2 - 9 } & &
\end{tabular}


Подовження таблиці 1

\begin{tabular}{|c|c|c|c|c|c|c|}
\hline \multirow{2}{*}{ 5G/4G PAI-1 } & 13 & 56 & 69 & & & \\
\hline & $38,2 \%$ & $51,4 \%$ & $48,3 \%$ & 0,238 & 1,71 & $0,78-3,75$ \\
\hline \multirow{2}{*}{ 4G/4G PAI-1 } & 2 & 35 & 37 & & & \\
\hline & $5,9 \%$ & $32,1 \%$ & $25,9 \%$ & 0,0015 & 7,57 & $1,72-33,38$ \\
\hline \multicolumn{7}{|c|}{$455 \mathrm{G} \rightarrow \mathrm{A}$ фібриногену $\beta$} \\
\hline \multirow{2}{*}{$455 \mathrm{GG}$} & 25 & 38 & 63 & & & \\
\hline & $73,5 \%$ & $34,9 \%$ & $44,1 \%$ & $<0,0001$ & 0,19 & $0,08-0,45$ \\
\hline \multirow{2}{*}{$455 \mathrm{GA}$} & 8 & 44 & 52 & & & \\
\hline & $23,5 \%$ & $40,4 \%$ & $36,4 \%$ & 0,102 & 2,2 & $0,91-5,30$ \\
\hline \multirow{2}{*}{$455 \mathrm{AA}$} & 1 & 27 & 28 & & & \\
\hline & $2,9 \%$ & $24,8 \%$ & $19,6 \%$ & 0,005 & 10,87 & $1,42-83,27$ \\
\hline
\end{tabular}

Кількість нормальних гомозигот 675 5G/5G гена PAI-1 в основній групі (16,5 \%) в 3,39 рази менше, ніж у контрольній групі (55,9 \%, $\mathrm{p}<0,05)($ ВШ=0,16, 95\%ДІ 0,07-0,36). Кількість патологічних гомозигот 675 4G/4G гена PAI-1 спостерігали в 4,39 рази частіше в О групі $(25,9 \%)$, ніж у контрольній групі $(5,9 \%, \quad \mathrm{p}<0,05) \quad$ (ВШ $=7,57$, 95\% ДІ 1,72-33,38).

Кількість нормальних гомозигот гена 455 GG FGB в О групі $(44,1 \%)$ знижена в 1,67 рази порівняно 3 контрольною групою (73,5 \%, p < 0,05) (ВШ=0,19, 95 \% ДІ 0,19-0,45), кількість патологічних гомозигот 455 AA FGB в О групі (19,6\%) вірогідно переважала показник основної групи $(2,9 \%, \mathrm{p}<0,05, \mathrm{BШ}=10,87,95 \%$ ДІ 1,42-83,27).

Ранговий коефіцієнт корреляції Спірмена між ЗНВ та поліморфізмом 5G/4G PAI-1 дорівнював 0,388 ( $<00,05)$, а 3 поліморфізмом в гені фібриногену $\beta 455 \mathrm{G} \rightarrow \mathrm{A} 0,344$ ( $<0,05)$ відповідно, тобто встановлено, що вказані маркери мають зв'язок середньої сили з НВ. 
Для прогнозування НВ за залежними предикторними змінними поліморфізмами PAI-1 та фібриногену $\beta$ застосовуємо бінарний логістичний регресійний аналіз. Модель побудована за допомогою біномінальної логістичної регресії, дихотомічна змінна результату приймає значення 1 - при встановленні у пацієнтки НB, 0 - за відсутності НВ. За допомогою бінарного логістичного регресійного аналізу було визначено, що імовірність НВ становить лінійну функцію незалежних перемінних: $y=a+b 1 \times x 1+b 2 \times x 2$ (1), де $-y-$ результат, $a-$ вільний член рівняння регресії, $b$ - регресійні коефіцієнти, $x_{-}$предикторні змінні (в даному випадку поліморфізми РАІ-1 та фібриногену $\beta$ ). Отримана нами функція ризику буде мати вигляд: $y=a+b P A I \times$ $x P A I+b F G B \times x F G B(2)$. Функцію (2) називаємо функцією ризику, iii значення обчислюється за значеннями $x_{P A l}, x_{F G B}$ та визначає імовірність розвитку НВ. Відповідно, після проведеного множинного регресійного аналізу, отримуємо такі крефіцієнти: $a=0,08047, \quad b_{P A l}=0,2019$, $b_{F G B}=0,1585$. Проведимо логіт-перевтілення функції ризику: $P=1 / 1+$ $\exp ^{-y}(3)$, де $P$ - вірогідність того, що відбудеться НВ (результат логіт-перевтілення).

Таким чином, рівняння прогностичної моделі ЗНВ має наступний вигляд:

$$
P=1 / 1+\exp ^{-y}=1 / 1+\exp ^{-(0,08047+0,2019 \times x P A I+0,1585 \times x F I B)}(4) .
$$

Статистична значимість рівняння перевірена за допомогою коефіцієнта детермінації і критерію Фішера. Встановлено, що в досліджуваній ситуації 22.82\% загальної варіабельності $y$ пояснюється зміною факторів $\mathrm{Xj}$. [5].

3'ясуємо, наскільки добре узгоджується запропонована модель (4) залежності ймовірності розвитку ЗНВ від чинників $x x_{P A I}, x_{F G B}$. Впорядковуємо значення функції ризику всіх вагітних (група О і група К) від мінімального до максимального і розбиваємо отримані значення на вісім частин, відповідно до критичних значень функції ризику (табл. 1). У першу групу увійшла частина вагітних, значення функції ризику у яких мінімальні, в останню, частина вагітних з максимальними значеннями функції ризику. Для кожної групи підраховуємо фактичне й прогнозоване число вагітних зі ЗНВ, також фактичне й прогнозоване число вагітних з нормальним перебігом вагітності (таблиця 2). 
Таблиця 2

Фактична та прогнозована кількість НВ

\begin{tabular}{|c|c|c|c|c|c|c|c|}
\hline \multirow{3}{*}{$\begin{array}{l}\text { Поряд- } \\
\text { ковий } \\
\text { номер }\end{array}$} & \multirow{3}{*}{$\begin{array}{c}\text { Значення } \\
\text { функції } \\
\text { ризику } y\end{array}$} & \multirow{3}{*}{$\begin{array}{c}\text { Значення } \\
\text { функції } \\
\text { ризику } \\
\text { після } \\
\text { логіт- } \\
\text { перевті- } \\
\text { лення } P(y)\end{array}$} & \multicolumn{4}{|c|}{ Число вагітних } & \multirow{3}{*}{ Загалом } \\
\hline & & & \multicolumn{2}{|c|}{ зі ЗНB } & \multicolumn{2}{|c|}{ здорових } & \\
\hline & & & $\begin{array}{l}\text { фак- } \\
\text { тичне }\end{array}$ & $\begin{array}{c}\text { прогно- } \\
\text { зоване }\end{array}$ & фактичне & $\begin{array}{c}\text { прогно- } \\
\text { зоване }\end{array}$ & \\
\hline 1 & 0,44 & 0,6084 & 8 & 15 & 17 & 10 & 25 \\
\hline 2 & 0,599 & 0,6455 & 7 & 6 & 2 & 3 & 9 \\
\hline 3 & 0,643 & 0,6555 & 15 & 14 & 7 & 8 & 22 \\
\hline 4 & 0,758 & 0,6808 & 3 & 2 & 0 & 1 & 3 \\
\hline 5 & 0,801 & 0,6994 & 39 & 31 & 6 & 14 & 45 \\
\hline 6 & 0,959 & 0,723 & 17 & 13 & 1 & 5 & 18 \\
\hline 7 & 1,003 & 0,7316 & 13 & 12 & 1 & 4 & 14 \\
\hline 8 & 1,161 & 0,7616 & 7 & 5 & 0 & 2 & 7 \\
\hline
\end{tabular}

Аналіз даних свідчить про те, що при значенні $P(0,801)=0,699$, число вагітних з фактичною й прогнозованою кількістю НВ різко підвищується, а число здорових зменшується. Тому значення $P(0,801)=0,699$ визначаємо як критичне. Перевищення такого значення свідчить про те, що вагітну потрібно відносити до групи високого ризику розвитку НВ. Чутливість запропонованої моделі становить 69,72 \% (95\% ДІ: 60,19 - 78,16 \%), специфічність - 76,47\% (95\% ДІ: 58,83 - 89,25\%), позитивна прогностична значимість (PPV) - 90,48 \% (83,66 - 94,66), негативна прогностична значимість (NPV) - 44,07\% $(35,92-52,55)$.

Висновки. Створену прогностичну модель звичного невиношування вагітності на підставі визначення наявності мутації генів PAI-1 (675 
5G/4G) та $\beta 455 \mathrm{G} \rightarrow \mathrm{A}$ з огляду на показники оцінки діагностичних методів вважаємо ефективною. Перевищення критичного значення $P(0,801)=0,699$ дозволяє виявити жінку високого ризику розвитку невиношування вагітності, дає змогу обрати раціональну тактику ведення вагітності та забезпечити виконання репродуктивних планів.

\section{Література:}

1. Adler, G., Mahmutbegovic, E. et al. Association Between - 675 ID, 4G/5G PAI-1 Gene Polymorphism and Pregnancy Loss: A Systematic Review. Acta Informatica Medica. 2018. 26(2), 156. https://doi.org/10.5455/ aim.2018.26.156-159

2. Barut, M., Bozkurt, M. et al. Thrombophilia and Recurrent Pregnancy Loss: The Enigma Continues. Medical Science Monitor. 2018. 24, 42884294. https://doi.org/10.12659/msm.908832

3. Bender Atik, R., Christiansen, O. et al. ESHRE guideline: recurrent pregnancy loss. Human Reproduction Open, 2018(2). https://doi.org/10.1093/hropen/hoy004

4. Papas, R., \& Kutteh, W. A new algorithm for the evaluation of recurrent pregnancy loss redefining unexplained miscarriage. Current Opinion In Obstetrics \& Gynecology. 2020. 32(5), 371-379 https://doi.org/10.1097/gco.0000000000000647

5. Лапач, С. Н., Чубенко, А. В., Бабич, П. Н. Статистические методы в медико-биологических исследованиях с использованием Excel. 2001. Київ: Мирион, С. 408. 